\title{
Mineral Contents of Several Indonesian Rice Varieties
}

\author{
*Susiyanti Susiyanti, Nurmayulis Nurmayulis, and \\ Sulastri Isminingsih \\ Department of Agroecotechnology, Agriculture Faculty, \\ University of Sultan Agung Tirtayasa, Serang, Banten Province, \\ Indonesia \\ *susiyanti@untirta.ac.id
}

\author{
Rahmayety Rahmayety and Yeyen Maryani \\ Department of Chemical Engineering, Engineering \\ Faculty, University of Sultan Agung Tirtayasa, Serang, \\ Banten Province, Indonesia \\ Rahmayety99@gmail.com
}

\author{
Suseno Amin \\ Department of Agroecotechnology, Agriculture Faculty \\ University of Padjajaran, West Jawa Province, Indonesia
}

Susenoamin73@gmail.com

\begin{abstract}
Rice is an important food commodity in the world, even the majority of Indonesia's population consumes rice as a staple food. The chemical composition of rice consumed is very complex. Rice contains organic ingredients and minerals. At present, the mineral as a nutrient has not been widely recognized by the public as well as the adequacy of calories, protein or vitamins. Analysis of mineral content in several Indonesian rice varieties (such as Kewal Bulu Hideung, Jalahawara, Pandan Wangi, Rojolele, Bendang Pulau, Batang Piaman, Cisantana, Sokan, Ciherang, Sidrap, and Kewal Gudril) carried out in Shimadzu laboratory, Osaka-Japan, using EDX-7000/8000 Energy-Dispersive X-ray Fluorescence Spectrometers. With these tools a variety of macro and micro minerals can be analyzed from each rice sample, including phosphorus $(P)$, potassium $(K)$, sulfur $(\mathrm{S})$, calcium $(\mathrm{Ca})$, manganese $(\mathrm{Mn})$, copper $(\mathrm{Cu})$, zinc $(\mathrm{Zn})$, iron (Fe), Rubidium $(\mathrm{Rb})$, silicon $(\mathrm{Si})$. Based on the results, the mineral content for various types of kinds of rice tested was varied. The highest mineral content was found in Kewal Bulu Hideung rice $(3.884 \%)$, and the lowest was Sokan $(1.677 \%)$. The mineral content found in succession from the largest to the smallest found in all rice tested were $P, K, S, C a$, and $\mathrm{Zn}$. The mineral content found only in special varieties were $\mathrm{Mn}, \mathrm{Fe}, \mathrm{Rb}, \mathrm{Si}, \mathrm{Cu}$.
\end{abstract}

Keywords : rice, variety, Indonesia, mineral content

\section{INTRODUCTION}

Rice is an important food commodity in the world, even most of the population of Indonesia consume rice as a staple food. The chemical composition of rice consumed is very complex. In addition to carbohydrate, rice has a mineral content that serves to other growth and development of the vital organs of a human being. According to [1], more than half of the world population is our suffering from bioavailable nutrient deficiencies particularly mainly in developing countries. Many things affect the mineral content contained in rice, such as the environment, genetic factors and process of rice miller and the other on food processing [2].

The mineral has an important function to human health, such as forming tissues of the body, regulate, and control the metabolic processes in the body. The mineral can be grouped into macrominerals $(\mathrm{Ca}, \mathrm{P}, \mathrm{Mg}, \mathrm{Na}, \mathrm{K}, \mathrm{Cl}, \mathrm{S})$ and micro minerals ( $\mathrm{Fe}, \mathrm{Zn}, \mathrm{Cu}, \mathrm{I}, \mathrm{Mn}, \mathrm{Cr}, \mathrm{Co}, \mathrm{Se}, \mathrm{Mo}, \mathrm{F})$. The demand for minerals that can be supplied through food consumption.

In Indonesia, rice, besides having a role in contributing to the adequacy of protein, energy, also plays a role in fulfilling minerals such as iron. Seeing these conditions, encourage plant breeders to assemble superior rice varieties that have good mineral content for health. For example, Bengawan Solo (high $\mathrm{Ca}$ ), Limboto ( $\mathrm{P}$ content) Cimelati (Fe content), and many others.

This mineral content is very needed by the body, but if found in excess content in food will cause a serious problem for health. Recently, heavy metal poisoning from foodstuffs has increased [3]. According to [4], heavy metal contamination in humans can also through food and water consumed. Environmental pollution by heavy metals can occur if industries that use these metals do not pay attention to environmental safety, especially when disposing of their waste. Hazardous metals in high concentrations will be very dangerous if found in water, soil and air environments [5]. Furthermore, all plants that grow on the contaminated soil will accumulate these metals in all parts (roots, stems, leaves, and fruit). Food produced from polluted environments will cause accumulation of contaminants into their organs.

Considering the position of rice which is considered as the world's important food and the main food of the Indonesian people, it is very necessary to inform the mineral content contained in the food they consume. Based on these problems, this study wants to examine the content of minerals in rice in some local Indonesian rice.

\section{MATERIALS AND METHODS}

Analysis of mineral content in several superior and local Indonesian rice varieties (such as Kewal Bulu Hideung, Jalahawara, Pandan Wangi, Rojolele, Bendang Pulau, Batang Piaman, Cisantana, Sokan, Ciherang, Sidrap, and Kewal 
Gudril) was carried out at Shimadzu Laboratory, Osaka Japan, using EDX-7000/8000 Energy-Dispersive X-ray Fluorescence Spectrometers. The EDX-7000/8000 incorporates a new high-performance semiconductor detector, provides excellent sensitivity, resolution, and throughput for an array of applications, from general screening analysis to advanced materials research in such fields as chemicals. With these tools various macro and micro minerals can be analyzed from each rice sample, including iron $(\mathrm{Fe})$, manganese $(\mathrm{Mn})$, copper $(\mathrm{Cu})$, zinc $(\mathrm{Zn})$, calcium $(\mathrm{Ca})$, magnesium $(\mathrm{Mg})$, sodium $(\mathrm{Na})$, potassium $(\mathrm{K})$, phosphorus $(\mathrm{P})$, sulfur $(\mathrm{S})$, boron (B), molybdenum (Mo), $\mathrm{Cu}$, nickel (Ni), and others.

\section{RESULTS AND DISCUSSION}

The rice used is a type of rice originating from several regions such as Banten area (Kewal Bulu Hideung, Jalahawara, Kewal Gudril), West Java (such as: Ciherang, Pandan Wangi, Rojolele), West Sumatra (Bendang Pulau, Batang Piaman, Sokan), Sulawesi (Cisantana, Sidrap). The physical appearance of the rice tested can be seen in Figure 1. From its appearance, the rice from Sidrap has a slender form, while the other rice is categorized based on the ratio of length per width as medium rice.

Based on the results of the analysis using EDX, the mineral content of $\mathrm{P}, \mathrm{K}, \mathrm{S}, \mathrm{Ca}, \mathrm{Mn}, \mathrm{Cu}, \mathrm{Zn}, \mathrm{Fe}, \mathrm{Rb}, \mathrm{Si}$ is obtained (can be seen in Table $1 \& 2$ ). The complete profile of the mineral content found in the Kewal Bulu Hideung rice can be seen in Figure 2; Jalahawara (Figure 3), Pandan Wangi (Figure 4), Rojolele (Figure 5), Bendang Pulau (Figure 6), Batang Piaman (Figure 7), Cisantana (Figure 8), Sokan (Figure 9), Ciherang (Figure 10), Sidrap (Figure 11), and Kewal Gudril (Figure 12).
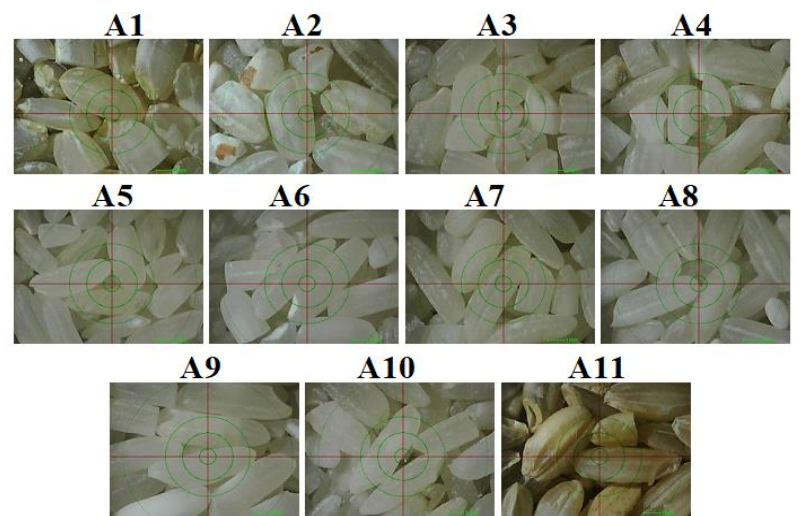

A10
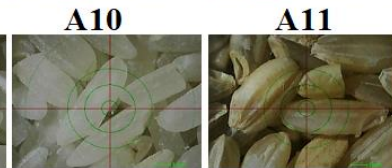

Figure 1. Physical appearance of rice samples: Kewal Bulu Hideung (A1), Jalahawara (A2), Pandan Wangi (A3), Rojolele (A4), Bendang Pulau (A5), Batang Piaman (A6), Cisantana (A7), Sokan (A8), Ciherang (A9), Sidrap (A10), and Kewal Gudril (A11).
TABLE 1.

Mineral Content of P, K, S, Ca, Mn, Cu ON Rice SOURCED From SEVERAL INDONESIAN RICE VARIETIES

\begin{tabular}{|c|l|c|c|c|c|c|c|c|}
\hline No. & $\begin{array}{l}\text { Jenis } \\
\text { Padi }\end{array}$ & P & K & S & Ca & Mn & Cu \\
\cline { 2 - 8 } & $\mathbf{( \% )}$ & \multicolumn{7}{|l|}{} \\
\hline 1 & $\begin{array}{l}\text { Kewal Bulu } \\
\text { Hideung }\end{array}$ & 2,157 & 1.246 & 0.196 & 0.001 & 0.004 & 0.001 \\
\hline 2 & Jalahawara & 1,126 & 0.393 & 0.381 & 0.031 & & \\
\hline 3 & Pandan Wangi & 1,525 & 0.431 & 0.274 & 0.014 & 0.003 & \\
\hline 4 & Rojolele & 1,361 & 0.39 & 0.254 & 0.01 & & \\
\hline 5 & $\begin{array}{l}\text { Bendang } \\
\text { Pulau }\end{array}$ & 1,131 & 0.3 & 0.229 & 0.008 & & \\
\hline 6 & $\begin{array}{l}\text { Batang } \\
\text { Piaman }\end{array}$ & 1,034 & 0.221 & 0.309 & 0.019 & & \\
\hline 7 & Cisantana & 1,823 & 0.54 & 0.271 & 0.025 & 0.003 & \\
\hline 8 & Sokan & 0.973 & 0.228 & 0.329 & 0.016 & & \\
\hline 9 & Ciherang & 1,565 & 0.405 & 0.221 & 0.019 & & \\
\hline 10 & Sidrap & 1,862 & 0.597 & 0.307 & 0.016 & & \\
\hline 11 & Kewal Gudril & 1.288 & 0.827 & 0.209 & 0.063 & 0.007 & \\
\hline & & & & & & & \\
\hline
\end{tabular}

The mineral content for various rice is varied (Table 1 $\& 2$, Figures 2 to 12). The highest mineral content was found in Kewal Bulu Hideung rice (3.884\%), and the lowest was Sokan $(1.677 \%)$. The mineral content found in all rice varieties is $\mathrm{P}$, $\mathrm{K}, \mathrm{S}, \mathrm{Ca}$, and $\mathrm{Zn}$. The mineral content found only in special varieties is $\mathrm{Mn}, \mathrm{Fe}, \mathrm{Rb}, \mathrm{Si}, \mathrm{Cu}$. The main minerals in rice are $\mathrm{Ca} \mathrm{Cl}, \mathrm{Na}, \mathrm{Si}, \mathrm{Fe}, \mathrm{P}$, and $\mathrm{K}$, followed by $\mathrm{Si}$ and $\mathrm{Mg}$ [6]. The rice in this study contained $\mathrm{Ca}, \mathrm{Zn}, \mathrm{Mn}, \mathrm{Fe}, \mathrm{Rb}, \mathrm{Si}$, and $\mathrm{Cu}$ which were low, while the $\mathrm{P}$ content was proportionally higher. The distribution of minerals in rice seeds is mostly found in the outer layer of the seeds and further downward. Many things affect the mineral content in plant organs, such as genetic factors, soil and water environment where the rice grows, and post-harvest processing.

TABLE 2.

Mineral Content of $\mathrm{Zn}, \mathrm{Fe}, \mathrm{Rb}, \mathrm{Si}$, ORganic Material, Total MINERALS on RICE SOURCED from SEVERAL INDONESIAN RICE VARIETIES

\begin{tabular}{|c|l|c|c|c|c|c|c|}
\hline \multirow{2}{*}{ No. } & Jenis Padi & Zn & Fe & Rb & Si & BO & Mineral \\
\cline { 2 - 8 } & \multicolumn{7}{|c|}{$(\mathbf{\%})$} \\
\hline 1 & $\begin{array}{l}\text { Kewal Bulu } \\
\text { Hideung }\end{array}$ & 0.006 & 0.006 & 0.005 & 0.264 & 96.116 & 3.884 \\
\hline 2 & Jalahawara & 0.003 & 0.002 & & & 98.063 & 1.937 \\
\hline 3 & Pandan Wangi & 0.003 & 0.003 & 0.002 & 0.016 & 97.578 & 2.422 \\
\hline 4 & Rojolele & 0.003 & & 0.002 & & 97.98 & 2.02 \\
\hline 5 & $\begin{array}{l}\text { Bendang } \\
\text { Pulau }\end{array}$ & 0.002 & & 0.003 & 0.113 & 98.213 & 1.787 \\
\hline 6 & $\begin{array}{l}\text { Batang } \\
\text { Piaman }\end{array}$ & 0.003 & & 0.003 & 0.189 & 98.223 & 1.777 \\
\hline 7 & Cisantana & 0.003 & 0.002 & 0.002 & 0.126 & 97.204 & 2.796 \\
\hline 8 & Sokan & 0.003 & & & 0.0128 & 98.323 & 1.677 \\
\hline
\end{tabular}




\begin{tabular}{|c|l|c|c|c|c|c|c|}
\hline 9 & Ciherang & 0.003 & & & & 97.787 & 2.213 \\
\hline 10 & Sidrap & 0.003 & 0.003 & & & 97.213 & 2.787 \\
\hline 11 & Kewal Gudril & 0.004 & 0.004 & 0.003 & 1.043 & 96.561 & 3.439 \\
\hline
\end{tabular}
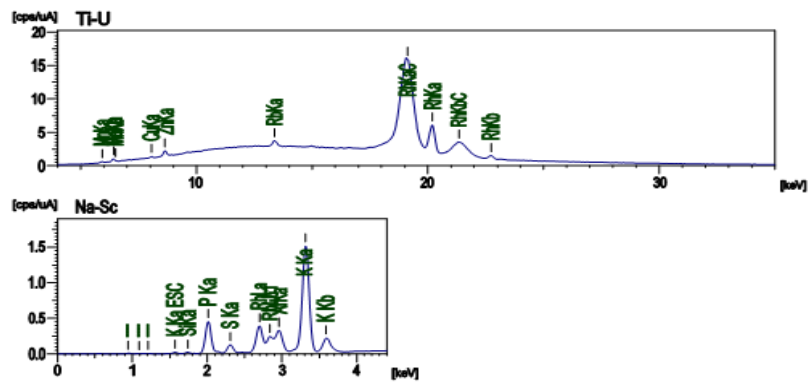

Figure 2. Profile of mineral content of Kewal Bulu Hideung rice
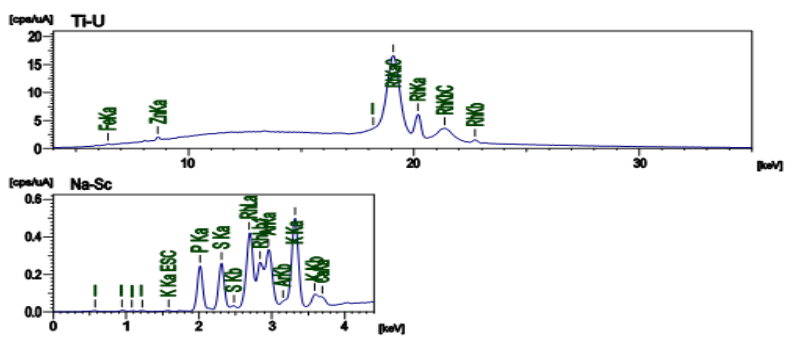

Figure 3. Profile of mineral content of Jalahawara rice

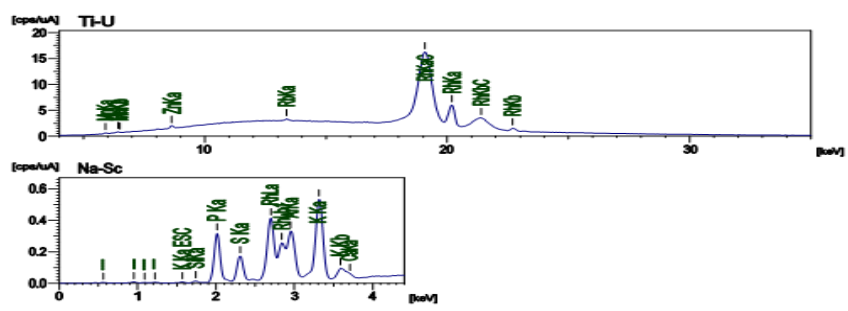

Figure 4. Profile of mineral content of Pandan Wangi rice

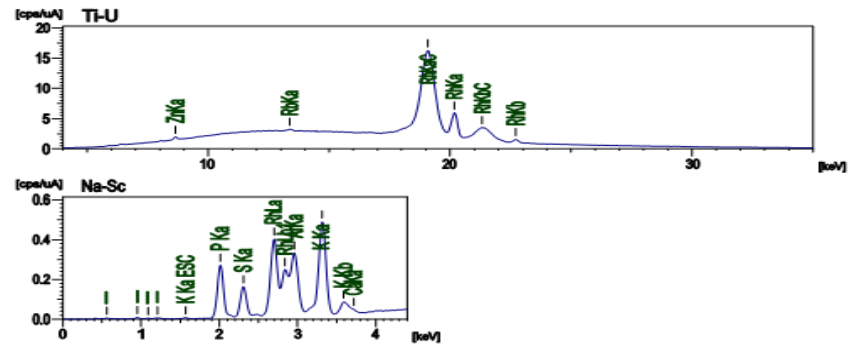

Figure 5. Profile of mineral content of Gambar Rojolele rice

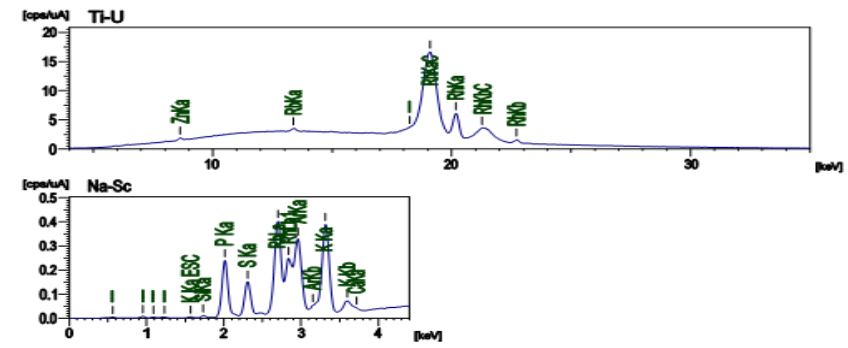

Figure 6. Profile of mineral content of Bendang Pulau rice

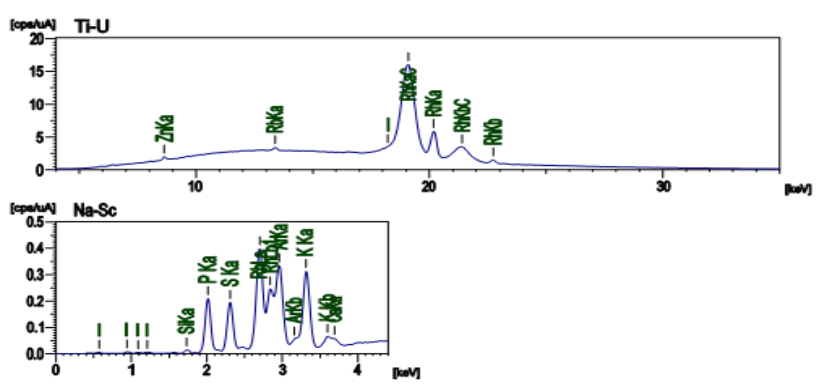

Figure 7. Profile of mineral content of Batang Piaman rice

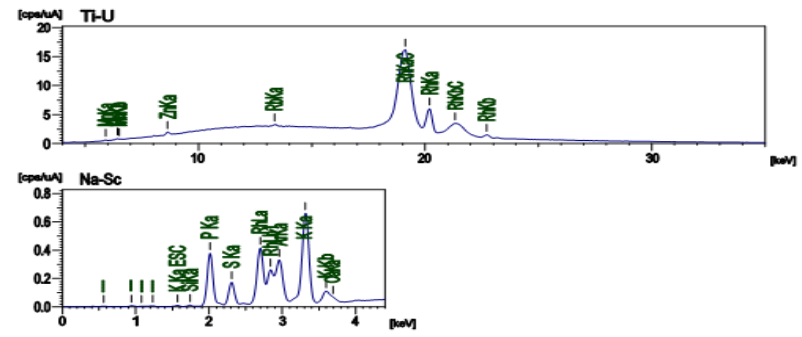

Figure 8. Profile of mineral content of Cisantana rice

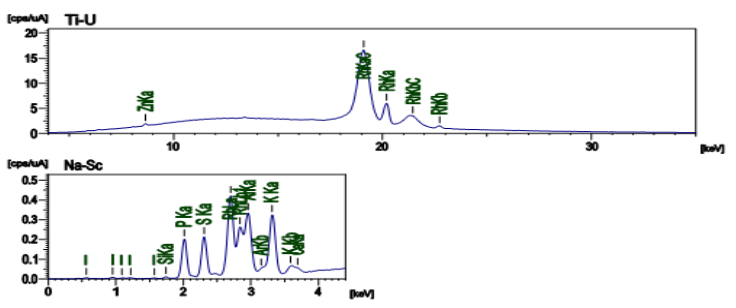

Figure 9. Profile of mineral content of Sokan rice

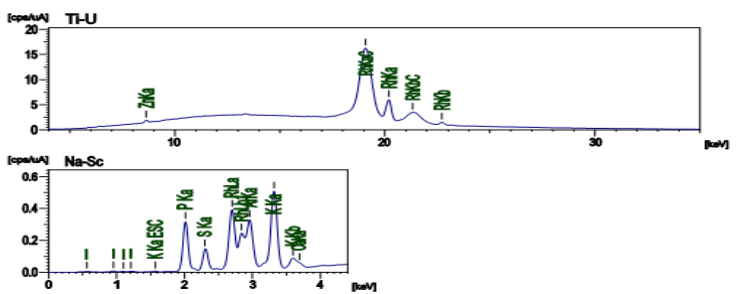

Figure 10. Profile of mineral content of Ciherang rice 


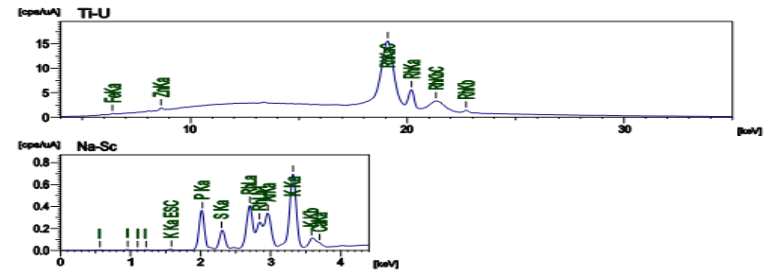

Figure 11. Profile of mineral content of Sidrap rice

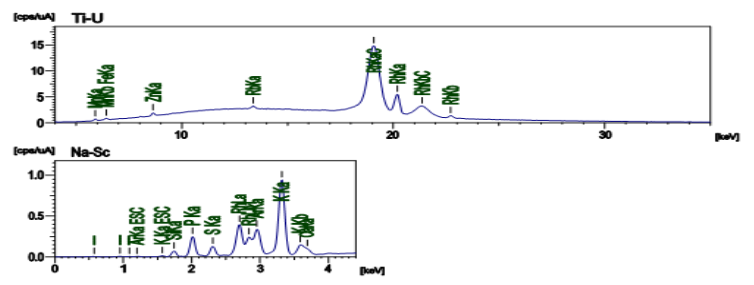

Figure 12. Profile of mineral content of Kewal Gudril rice

The results showed a range of $\mathrm{P}, \mathrm{K}$ and $\mathrm{Ca}$ contents respectively $0.973-2.157 \%$ for $\mathrm{P}$; $0.221-1.246 \%$ for $\mathrm{K}$; and $0.001-0,382 \%$ for $\mathrm{Ca}$. Based on research, [7] reported rice mineral content in Nigerian rice varieties, such as $\mathrm{P}$ content (0.52-0.54\%); K (0.15-0.20\%); Ca (0.09-0.11\%). This means that Indonesian rice that has been studied has a higher $\mathrm{P}$ and $\mathrm{K}$ content, while it Ca content is lower. According to [8], P, K, and $\mathrm{Ca}$ accumulated around the aleurone layer, and most widely found on the lateral side of the rice seed.

The results of the study in Table 1 show that the $\mathrm{Cu}$ content is $0.001 \%$ (only found in Kewal Bulu Hideung), while the $\mathrm{Zn}$ content ranges from $0.002-0.006 \%$ (Table 2). The content of $\mathrm{Cu}$, and $\mathrm{Zn}$ in aromatic and non-aromatic rice in India, found that the $\mathrm{Cu}$ content ranged from 0.0041$0.01595 \%$; and $\mathrm{Zn} 0.0093-0.017 \%$ [9]. When compared, the content of $\mathrm{Cu}$ and $\mathrm{Zn}$ was found in all samples of rice varieties tested in this study, apparently lower than the rice studied in India. $\mathrm{Zn}$ and $\mathrm{Cu}$ were found on localization different from $\mathrm{P}$, because the $\mathrm{Zn}$ and $\mathrm{Cu}$ were the most abundant in endosperm in the closed position layer (i.e. the layer of sub-aleurone), and spread deeper into the endosperm [8].

The $\mathrm{Fe}$ content of the analysis ranges from 0.002$0.006 \%$ and is only found in Kewal Bulu Hideung, Jalahawara, Pandan Wangi, Cisantana, Sidrap, Kewal Gudril. The Fe content in these varieties is generally higher when compared to the $\mathrm{Fe}$ content in rice studied by [9], which is 0.0008 $0.0031 \%$. The localization sites of the aleurone layer and the inner starch endosperm. The pattern of distribution of $\mathrm{Fe}$ abounds in the dorsal side, where some vascular bundles, present and acting as a gateway for translocation [8] .

Mn content in this study ranged from $0.005-0.007 \%$ found in several varieties, namely Kewal Bulu Hideung, Pandan Wangi, Cisantana and Kewal Gudril. In the body, Mn acts as a catalyst for several important metabolic reactions in proteins, carbohydrates, and fats. In protein metabolism, Mn activates the conversion of amino acids with specific enzymes such as arginase, prolinase, dipeptidase. In carbohydrate metabolism, Mn plays an active role in several conversion reactions in glucose oxidation and synthesis of oligosaccharides. In fat metabolism, Mn acts as a cofactor in the synthesis of long chain fatty acids and cholesterol.

The content of a metal content in plant organs will also be affected by the availability of other metals. According to [10], the hull of high accumulation of the elements, such as $\mathrm{N}$ and $\mathrm{P}$ from the hull into the brown rice. The levels of $\mathrm{Si}$ ranged from 0.016-1.043\% found in the Kewal Bulu Hideung rice, Pandan Wangi, Bendang Pulau, Batang Piaman, Cisantana, and Kewal Gudril.

In this study, $\mathrm{Rb}$ content of $0.002-0.005 \%$ was found in Kewal Bulu Hideung rice, Pandan Wangi, Rojolele, Bendang Pulau, Cisantana, and Kewal Gudril. The Rb concentration in white grain ranged from 1.2-5.5 mg kg-1 $(0.0012-0.0055 \%)$ in rice on the Swedish market [11]. There is still very little literature that discusses the usefulness of $\mathrm{Rb}$ in plants.

The types of essential heavy metals found in this study are $\mathrm{Zn}, \mathrm{Cu}, \mathrm{Fe}$, and $\mathrm{Mn}$, in certain quantities that are needed by living things, but if found in excessive amounts it will cause toxic effects. However, the mineral content found in this study showed no potential for causing poisoning. According to [12] and [3] types of heavy metals that are toxic to humans such as: arsenic (As), cadmium $(\mathrm{Cd})$, copper $(\mathrm{Cu})$, lead $(\mathrm{Pb})$, mercury $(\mathrm{Hg})$, nickel $(\mathrm{Ni}),(\mathrm{Zn})$, however, in the results this study found no type of heavy metal. From the description above, it can be assumed that the origin of the location and the environment of planting the sampled rice is still relatively safe and the rice has a reasonable mineral content for consumption.

\section{CONCLUSION}

The mineral content for various types of rice that have been tested is varied. The highest mineral content was found in Kewal Bulu Hideung rice $(3.884 \%)$, and the lowest was Sokan $(1.677 \%)$. The mineral content found in succession from the largest to the smallest found in all rice tested was $\mathrm{P}, \mathrm{K}, \mathrm{S}, \mathrm{Ca}$, and $\mathrm{Zn}$. The mineral content found only in certain varieties of rice is $\mathrm{Mn}, \mathrm{Fe}, \mathrm{Rb}, \mathrm{Si}, \mathrm{Cu}$.

\section{ACKNOWLEDGMENT}

Thank you for the Islamic Development Bank which has funded this research as part of the RC Biotechnology participation in University of Sultan Ageng Tirtayasa, 2018. Thank you also said to the Shimadzu Laboratory, Osaka-Japan which facilitated this research.

\section{REFERENCES}

[1] Z. Shahzad, H. Rouached, A. Rakha, "Combating mineral malnutrition through iron and zinc biofortification of cereals", Compr. Rev. Food Sci. Food Saf. 13:329-346, 2014 
[2] W.R. Rohaeni, E. Supriadi, U. Susanto, and T.D. Rosahdi, "Kandungan Fe dan Zn pada beras pecah kulit dan beras sosoh dari galur-galur padi toleran wereng batang cokelat ( $\mathrm{Fe}$ and $\mathrm{Zn}$ content of brown rice and milled rice on brown planthopper tolerant rice lines)", Jurnal Ilmu Pertanian Indonesia , 21 (3): 172-176, 2016

[3] D. Sundari, M. Hananto, dan Suharjo," Kandungan logam berat dalam bahan pangan di kawasan industri kilang minyak, Dumai (Heavy metal in food ingredients in oil refi nery industrial area, Dumai", Buletin Penelitian Sistem Kesehatan, 19 (1): 55-61, 2016

[4] T. Agustina, "Kontaminasi logam berat pada makanan dan dampaknya pada kesehatan", Teknobuga, 1(1): 53-65, 2014

[5] M. Astawan, "Bahaya logam berat dalam makanan". Available on: http://edukasi.kompas.com/, read/2008/09/21/11254074/Bahaya.Logam .Berat. alam.Makanan, 2008

[6] S.D. Indrasari, P. Wibowo, A.A. Darajat, "Kandungan mineral beras varietas unggul baru" Prossiding seminar nasional padi. Source: http://www.litbang.deptan.go.id/special/padi/bbpadi_2008_ proeb412.pdf., 2008

[7] A.O. Oko, and S.I. Ugwu,'The proximate and mineral compositions of five major rice varieties in Abakaliki, South-Eastern Nigeria", International Journal of Plant Physiology and Biochemistry. 3(2): 2527. http://www.academicjournals.org/ijppb ISSN-2141-2162, 2011

[8] T. Iwai, M. Takahashi, O. Oda, Y. Terada., K.T. Yoshida, "Dynamic changes in the distribution of minerals in relation to phytic acid accumulation during rice seed development", Plant Physiology Preview. DOI: https://doi.org/10.1104/pp.112.206573, . 2012

[9] D.K. Verma, and P.P. Srivastav, "Proximate Composition, Mineral Content and Fatty Acids Analyses of Aromatic and Non-Aromatic Indian Rice" Rice Science 24(1):21-31. January 2017

[10] T.H. Ansari, K. Iwasaki,T. Yoshida, Y. Yamamoto, and A. Miyazaki, "Status of nutrient elements in rice grain in relation to silicon accumulation pattern during grain filling”. Bangladesh Agron. J. 19(2): 125-137 S, 2016

[11] L. Jorhem, C.Åstrand, B. Sundström, M. Baxter, P.Stokes, J. Lewis, K.P. Grawé, "Elements in rice on the Swedish market: Part 2. Chromium, copper, iron, manganese, platinum, rubidium, selenium and zinc" Food Addit. Contam. 25:841-850, 2016

[12] WHO, "WHO guidelines for indoor air: Selected pollutants: WHO Regional Office for Europe. Denmark, 2010 